\title{
Elemental and isotopic carbon and nitrogen records of organic matter accumulation in a Holocene permafrost peat sequence in the East European Russian Arctic
}

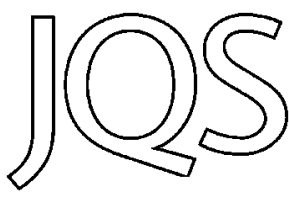

\author{
RINA ARGELIA ANDERSSON, ${ }^{1 *}$ PHILIP MEYERS, $^{2}$ EDWARD HORNIBROOK, ${ }^{3}$ PETER KUHRY $^{4}$ and CARL-MAGNUS MÖRTH ${ }^{1}$ \\ ${ }^{1}$ Department of Geological Sciences, and Quaternary Geology, Stockholm University, SE-106 91 Stockholm Sweden \\ ${ }^{2}$ Department of Earth and Environmental Sciences, The University of Michigan, Ann Arbor, MI, USA \\ ${ }^{3}$ Bristol Biogeochemistry Research Centre \& Cabot Institute, School of Earth Sciences, University of Bristol, UK \\ ${ }^{4}$ Department of Physical Geography and Quaternary Geology, Stockholm University, SE-106 91 Stockholm Sweden \\ Received 22 July 2011; Revised 28 February 2012; Accepted 29 February 2012
}

\begin{abstract}
A peat deposit from the East European Russian Arctic, spanning nearly 10000 years, was investigated to study soil organic matter degradation using analyses of bulk elemental and stable isotopic compositions and plant macrofossil remains. The peat accumulated initially in a wet fen that was transformed into a peat plateau bog following aggradation of permafrost in the late Holocene $(\sim 2500 \mathrm{cal}$ a BP). Total organic carbon and total nitrogen $(\mathrm{N})$ concentrations are higher in the fen peat than in the moss-dominated bog peat layers. Layers in the sequence that have lower concentrations of total hydrogen $(\mathrm{H})$ are associated with degraded vascular plant residues. $\mathrm{C} / \mathrm{N}$ and $\mathrm{H} / \mathrm{C}$ atomic ratios indicate better preservation of organic matter in peat material dominated by bryophytes as opposed to vascular plants. The presence of permafrost in the peat plateau stage and water-saturated conditions at the bottom of the fen stage appear to lead to better preservation of organic plant material. $\delta^{15} \mathrm{~N}$ values suggest $\mathrm{N}$ isotopic fractionation was driven primarily by microbial decomposition whereas differences in $\delta^{13} \mathrm{C}$ values appear to reflect mainly changes in plant assemblages. Positive shifts in both $\delta^{15} \mathrm{~N}$ and $\delta^{13} \mathrm{C}$ values coincide with a local change to drier conditions as a result of the onset of permafrost and frost heave of the peat surface. This pattern suggests that permafrost aggradation not only resulted in changes in vegetation but also aerated the underlying fen peat, which enhanced microbial denitrification, causing the observed ${ }^{15} \mathrm{~N}$-enrichment. Copyright (C) 2012 John Wiley \& Sons, Ltd.
\end{abstract}

KEYWORDS: Arctic peatlands; permafrost; stable isotopes; elemental analyses; macrofossil analyses.

\section{Introduction}

Large amounts of carbon $(\mathrm{C})$ and nitrogen $(\mathrm{N})$ are stored in northern peatlands (Limpens et al., 2006; Tarnocai et al., 2009), and soil organic matter (SOM) in peat deposits plays a significant role in the global biogeochemical cycles of these important elements. Destabilization of the enormous stocks of peat SOM can potentially lead to accelerated emissions of greenhouse gases to the atmosphere (Davidson and Janssens, 2006). A positive feedback to climate change may result from degradation of peatland SOM as a consequence of warming at high latitudes, which are the regions most sensitive to climate change (Lemke et al., 2007). Mechanisms that control degradation and stabilization of organic matter have been widely studied in recent years (Kracht and Gleixner, 2000; Davidson and Janssens, 2006), but much remains to be done to better understand these processes under different eco-climatic scenarios.

Stable isotope analysis of peat and other geological materials is an important tool for gaining insight into biogeochemical processes involved in SOM degradation and preservation (Balesdent et al., 1987; Nadelhoffer et al., 1996; Kracht and Gleixner, 2000) and also in paleoclimate studies (Jones et al., 2010; Kaislahti Tillman et al., 2010). However, interpretation of such records is not straightforward because many factors affect and control stable isotope variations. In addition, a large variety of vascular plants, mosses, algae, fungi, microorganisms and sedimentation processes influence the $\mathrm{C}$ and $\mathrm{N}$ isotope compositions of SOM.

Peat deposits are archives of ecosystem development, plant succession and past regional climate (Barber, 1993). Organic matter accumulated in these systems contains elemental and isotopic records that potentially can be used to reconstruct past

*Correspondence: R. A. Andersson, as above.

E-mail: rina.garcia@geo.su.se environmental conditions and cycling of $\mathrm{C}$ and $\mathrm{N}$. Traditional methods and techniques in the study of past vegetation assemblages and degradation of peat include the analyses of plant macrofossil residues and peat humification (Chambers et al., 2012). A disadvantage of the macrofossil method is the difficulty in properly identifying highly decomposed plant remains. The peat humification technique based on the alkaline extraction of humic matter imposes uncertainties on the interpretation of the measured signal, which is usually considered an indicator of decay; however, some results suggest that it may instead be a measure of initial botanical chemical compositions (Caseldine et al., 2000). These potential limitations of traditional methods and techniques point towards the necessity of using alternative, complementary proxies for paleoenvironmental studies based on peat sequences.

To evaluate the effects of Holocene environmental changes on organic matter preservation and to investigate evidence of past $\mathrm{C}$ and $\mathrm{N}$ cycling in a peat sequence, we measured the concentrations of carbon, nitrogen and hydrogen $(\mathrm{H})$, the atomic $\mathrm{H} / \mathrm{C}$ and $\mathrm{C} / \mathrm{N}$ ratios, and the stable $\mathrm{C}$ and $\mathrm{N}$ isotope compositions of organic matter in a peat core from the European Russian Arctic. These parameters are influenced by the biochemical plant compositons, peat diagenesis, and local and regional environmental events that drove changes in vegetation assemblages. We also incorporated plant macrofossil analyses in the study to complement and facilitate interpretation of the organic geochemical data.

\section{Interpretive foundations for the organic matter elemental and isotopic compositions}

Elemental compositions and atomic $C / N$ and $\mathrm{H} / \mathrm{C}$ ratios

Elemental ratios derived from organic matter $\mathrm{C}, \mathrm{N}$ and $\mathrm{H}$ concentrations can provide information about the sources and 
preservation of this material. Atomic $\mathrm{C} / \mathrm{N}$ ratios between 20 and 50 are typical of the vascular and mossy plants that are important to peat accumulations (e.g. Meyers, 1994). These relatively high $\mathrm{C} / \mathrm{N}$ ratios commonly exist in shallow layers of recently deposited peat that has not undergone significant decomposition. In non-permafrost peatlands, $\mathrm{C} / \mathrm{N}$ ratios decrease markedly in deeper peat layers as a result of progressive decomposition that removes more carbon than nitrogen (Kuhry and Vitt, 1996). In contrast, high $\mathrm{C} / \mathrm{N}$ ratios are largely preserved in permafrost peatlands because perennially frozen conditions inhibit decomposition of organic matter (Vardy et al., 2000).

Atomic $\mathrm{H} / \mathrm{C}$ ratios in a peat profile can also provide clues to the chemical constitution and quality of the peat. Algal, herbaceous, woody and coaly sedimentary organic matter contain different proportions of hydrogen (Talbot and Livingstone, 1989). Algal organic matter tends to have more hydrogen-rich aliphatic components, whereas herbaceous and woody materials have increasingly more hydrogendepleted aromatic components. Carbonaceous residues in coaly material have very low $\mathrm{H}$ contents (Talbot and Livingstone, 1989). These characteristics are reflected in atomic $\mathrm{H} / \mathrm{C}$ ratios that also provide insight into the preservation of peat material (e.g. Ortiz et al., 2004). Saturated H-rich organic compounds are characterized by high $\mathrm{H} / \mathrm{C}$ ratios and tend to be readily consumed by bacteria. Algal material is consequently rapidly removed relative to herbaceous and woody materials. In addition, hydrogen-rich cellulose is more readily degraded than lignin-derived aromatic compounds, which tend to be more resistant to humification processes (Benner et al., 1987; Kracht and Gleixner, 2000).

\section{$\delta^{13} \mathrm{C}$ and $\delta^{15} \mathrm{~N}$ values}

The $\delta^{13} \mathrm{C}$ value of organic matter is a sensitive paleoenvironmental indicator that can provide information about ancient biogeochemical processes (Hayes, 1993) and has been investigated in permafrost and non-permafrost peats (Ortiz et al., 2004; Alewell et al., 2011). Plant $\delta^{13} \mathrm{C}$ values are principally determined by photosynthetic processes (Farquhar et al., 1989), but external factors can also affect ${ }^{13} \mathrm{C} /{ }^{12} \mathrm{C}$ ratios. Ménot and Burns (2001) determined that atmospheric $\mathrm{CO}_{2}$ concentration, growth temperature and water stress influence $\delta^{13} \mathrm{C}$ values of vascular plants and mosses in ombrotrophic bogs. Additional ${ }^{13} \mathrm{C}$ fractionation can result from interactions between roots, microorganisms and soil organic matter (Werth and Kuzyakov, 2010). Analysis of different tissues has identified heterogeneity in $\delta^{13} \mathrm{C}$ values in a single plant (Balesdent et al., 1987), including branches and stems in Sphagnum (Loader et al., 2007; Moschen et al., 2009).

Degradation of organic matter may produce ${ }^{13} \mathrm{C}$-enrichment in residual material because bacteria preferentially metabolize the ${ }^{12}$ C-rich fraction (Skrzypek et al., 2007). An increase in $\delta^{13} \mathrm{C}$ values with depth and age in organic matter has been reported in different soils (e.g. Balesdent and Mariotti, 1998; Bol et al., 1999). However, other studies have reported that during decomposition of vascular plant debris, selective assimilation of polysaccharides by bacteria produces a lignin-rich residue, resulting in more negative $\delta{ }^{13} \mathrm{C}$ values because lignins are ${ }^{13} \mathrm{C}$-depleted relative to cellulose (e.g. Benner et al., 1987). On the other hand, the isotopic source information of organic matter can be preserved in sediments for millions of years (Meyers, 1994). Skrzypek et al. (2010) also demonstrated that $\delta^{13} \mathrm{C}$ values of peat remain well preserved and mainly reflect the $\mathrm{C}$ isotope composition of original peatforming plant debris rather than post-depositional decay processes.

The stable isotope composition of nitrogen in wetland vegetation and peat has been less studied than carbon, and few data sets are available for comparison. Nadelhoffer (1996) reported that $\mathrm{N}$ mineralization of tundra plants and soil resulted in $\mathrm{N}$ isotope fractionation, causing more positive $\delta^{15} \mathrm{~N}$ values with depth and age of organic matter. During degradation, microorganisms appear to preferentially utilize ${ }^{14} \mathrm{~N}$, leaving soil organic matter ${ }^{15} \mathrm{~N}$-enriched, although nitrogen uptake by plants also may contribute to partitioning of ${ }^{15} \mathrm{~N}$ and ${ }^{14} \mathrm{~N}$ (Nadelhoffer et al., 1996).

\section{Study area, materials and methods}

\section{Lek-Vorkuta peat plateau}

The peat profile was collected from a peat plateau in LekVorkuta, Russia (Fig. 1). The region is located in the lowland tundra of North-east European Russia $\left(67^{\circ} 25^{\prime} \mathrm{N}, 63^{\circ} 22^{\prime} \mathrm{E}\right)$ ca. $35 \mathrm{~km}$ south-west of the city of Vorkuta in an area characterized by discontinuous permafrost. Modern vegetation covering the dry elevated flat surface of the peat plateau is dominated by dwarf shrubs such as Vaccinium vitis-idaea (lingonberry) and Ledum palustre (wild rosemary) and by lichens.

\section{Peat collection}

The LVPS4 peat section was collected in August 1999 by cutting slices from the upper $100 \mathrm{~cm}$ of the peat sequence
Figure 1. Map showing the study site in Lek-Vorkuta taken from Andersson et al. (2011), with land vegetation cover taken from Virtanen et al. (2004). This figure is available in colour online at wileyonlinelibrary.com/ journal/jqs.
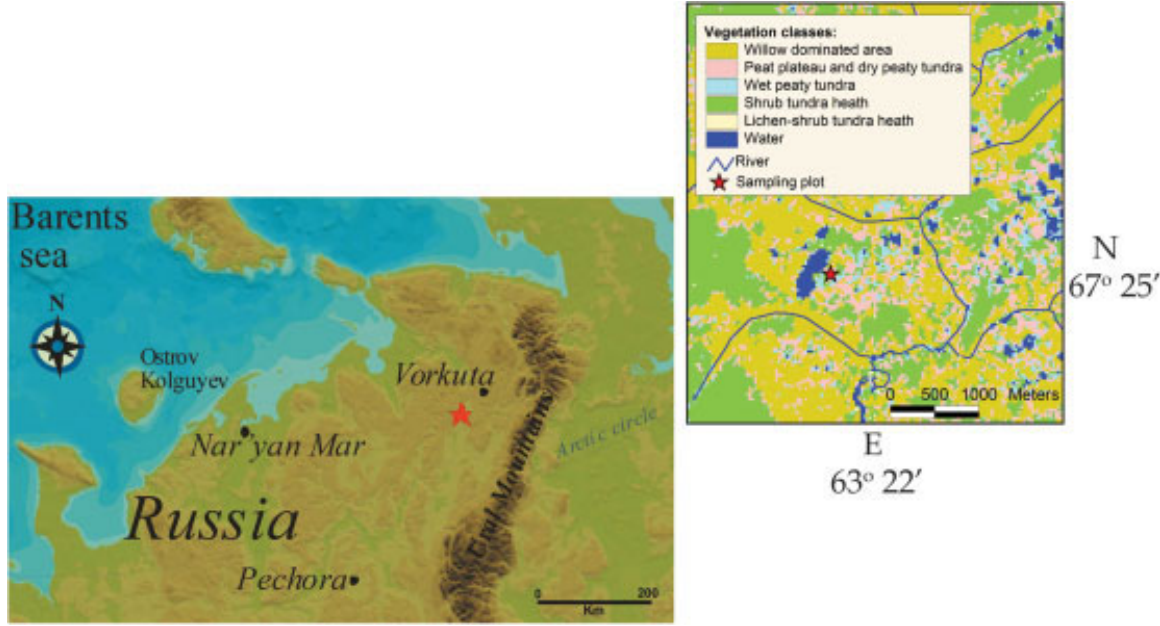

$63^{\circ} 22^{\prime}$ 
exposed next to a thermokarst lake. Core LVPS5B $(100-240 \mathrm{~cm})$ was collected in July $2000 \mathrm{ca}$. $40 \mathrm{~m}$ to the south-west of section LVPS4 by hammering a steel pipe into the frozen peat and extracting subsamples at ca. 10-cm intervals. Neither plant macrofossil nor geochemical records show abrupt transitions between the two profiles at the 100-cm level. The composite profile is consequently considered a continuous sequence that is hereafter referred to as core LVPS4 $+5 \mathrm{~B}$.

\section{Plant macrofossil and radiocarbon analyses}

Botanical remains in 12 peat samples were analyzed as described by Andersson et al. (2011). Four of those macrofossil samples were radiocarbon-dated. Plant macrofossil analysis of peat from $220 \mathrm{~cm}$ depth was performed because of geochemical changes observed at that horizon.

\section{Elemental and isotopic analyses}

Frozen peat samples were freeze-dried and then ground using a ball mill (Retsch $\mathrm{GmbH}$ type MM2). Two to three mg of each sample was used for elemental analysis (Carlo Erba NC2500). Total carbon $(\mathrm{C})$, hydrogen $(\mathrm{H})$ and nitrogen $(\mathrm{N})$ contents were measured simultaneously at $1000{ }^{\circ} \mathrm{C}$ with respective standard deviations of $0.153,0.117$ and $0.089 \%$ (reproducibility). Five samples along the core were analyzed in duplicate. The second analysis included sample treatment with acid to remove any carbonate carbon. The two results showed no difference, and therefore we considered the total carbon content to be equivalent to the total organic carbon (TOC) in all samples. For carbon and nitrogen stable isotopic analyses, samples were combusted in an elemental analyzer (Carlo Erba NC2500) connected to a Finnigan MAT Delta $V$ mass spectrometer using CONFLO IV. Stable carbon and nitrogen isotope results are expressed in parts per thousand (\%) relative to the VPDB (Vienna PeeDee Belemnite) standard and air, respectively. Based on repeated standard measurements, $\delta^{13} \mathrm{C}$ and $\delta^{15} \mathrm{~N}$ values were better than $\pm 0.15 \%$.

\section{Results and discussion}

\section{History of Lek-Vorkuta peatland based on plant macrofossil analyses}

Changes in vegetation during the Holocene development of this peatland are described in Andersson et al. (2011) and summarized in Fig. 2. The inception of this peatland was probably through paludification. It subsequently developed into a rich wet fen $\sim 9500 \mathrm{cal}$ a BP (section A1 at the base of the profile) dominated by brown mosses (Calliergon). Vegetation in the wet fen then became progressively dominated by vascular plants (mostly sedges) for almost 5000 years (section A2) before the onset of permafrost ca. $2500 \mathrm{cal}$ a BP (radiocarbon date in Fig. 2). The macrofossil analyses suggest that this event took place when frost heave of the peatland surface caused drier, ombrotrophic conditions, which led to radical changes in vegetation. The abundance of Cenococcum sclerotia is evidence of drier conditions (Coleman et al., 1989). The system subsequently developed into a peat plateau bog (section B) consisting of alternating stages dominated by mosses (Bs layers, relatively dry) and vascular plants ( $\mathrm{Br}$ layers, dry). Oksanen et al. (2001) reported similar stages in the Holocene development of other peatlands in this region.

\section{TOC, $\mathrm{N}$ and $\mathrm{H}$ concentrations}

TOC concentrations in core LVPS4 + 5B range from 43 to 50\%, averaging $45.3 \mathrm{wt} \%$ (weight percent) in the bog peat (B) and $47.7 \mathrm{wt} \%$ in the fen peat (A) (Fig. 3), which are typical for peat deposits (Vardy et al., 2000; Sannel and Kuhry, 2009). The lowest TOC concentrations appear in bog peat (B) in the Sphagnum (Bs)-dominated stages and also at the top of the profile (vascular plant-dominated, Br). Low TOC concentrations in samples from the present peat surface are due possibly to dust deposition (ash contents were not measured) during periods of slow peat accumulation. Peat accumulation ceased ca. 800 a BP (Andersson et al., 2011). Low TOC concentrations near the bottom of the sequence (section A1) may record mixing of peat with underlying mineral subsoil by cryoturbation.

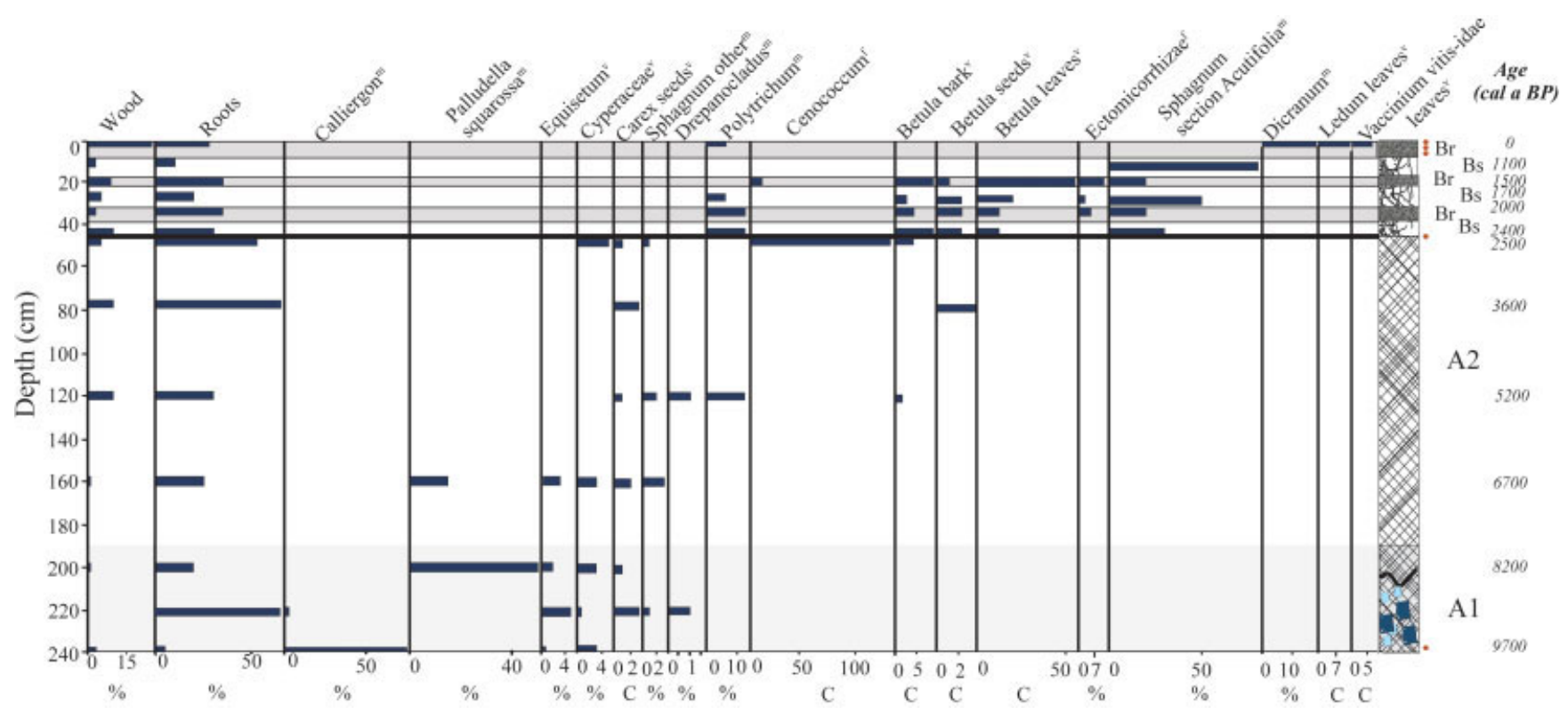

Figure 2. Distribution of plant macrofossils in the LVPS4 + 5B peat sequence reported in Andersson et al. (2011) and new macrofossil data at $220 \mathrm{~cm}$ depth. Superscripts $\mathrm{m}, \mathrm{v}$ and $\mathrm{f}$ after plant names indicate moss, vascular plant and fungi, respectively. Distributions are expressed as volume percentages of the total sample (\%) or as counts per $5 \mathrm{~cm}^{3}$ of analyzed material (C). Zone A corresponds to fen peat deposits and zone B to bog peat deposits. A1, fen deposits dominated by brown mosses; A2, fen deposits dominated by vascular plants; Br, rootlet layers in bog deposits; Bs, Sphagnum peat layers in bog deposits. The five dots on the right indicate those depths at which samples were taken for radiocarbon analysis. Approximate ages (cal a BP, based on linear interpolation) are shown. (Plant macrofossil analyses were conducted by P. Kuhry.) 


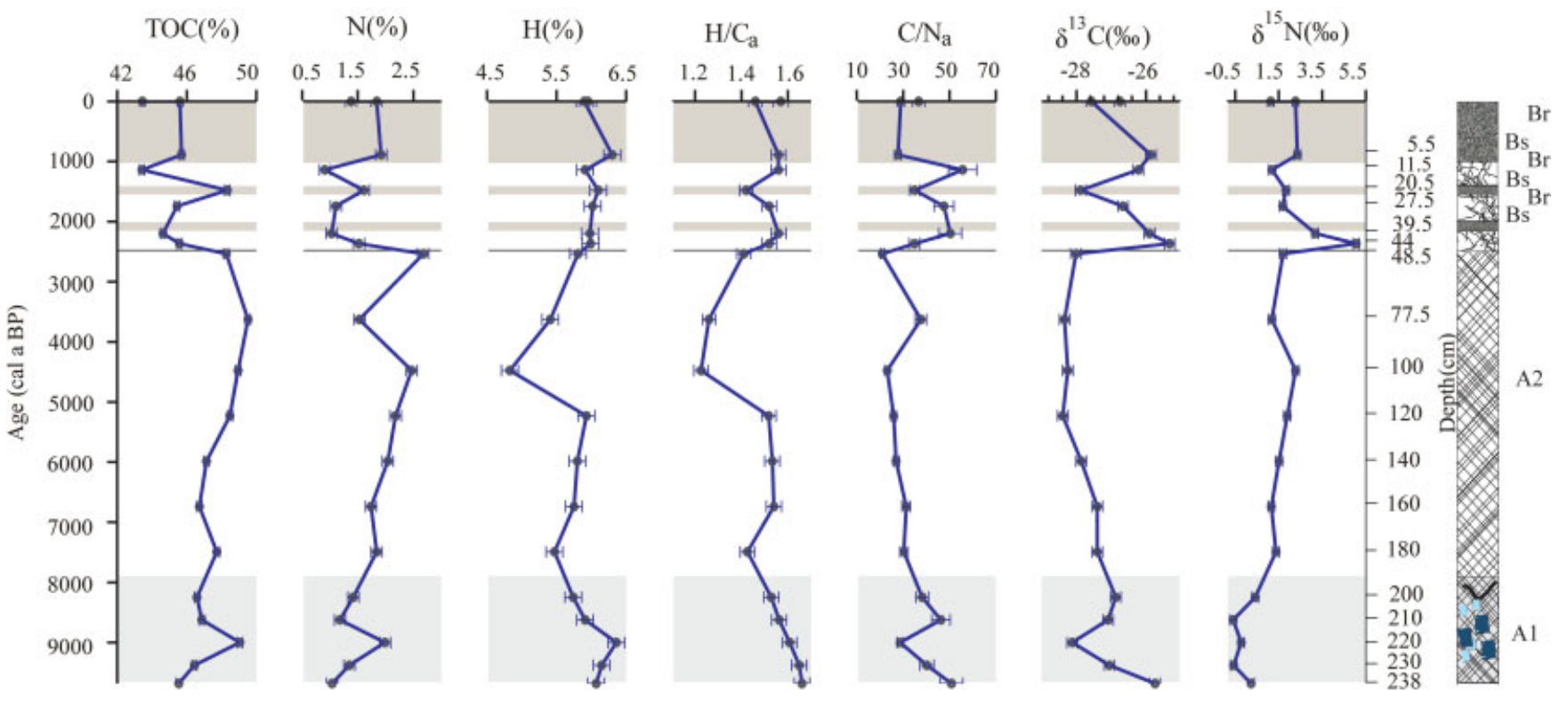

Figure 3. Total organic carbon (TOC) (wt \%), total $\mathrm{N}(\mathrm{wt} \%), \mathrm{H}(\mathrm{wt} \%), \mathrm{H} / \mathrm{C}, \mathrm{C} / \mathrm{N}$ and bulk peat $\delta^{13} \mathrm{C}$ and $\delta^{15} \mathrm{~N}$ values in the Lek-Vorkuta LVPS $4+5 \mathrm{~B}$ peat sequence as a function of time (linear interpolation based on calibrated radiocarbon ages). Gray bars indicate the positions of the rootlet layers $(\mathrm{Br})$. Error bars are included. This figure is available in colour online at wileyonlinelibrary.com/journal/jqs.

Nitrogen concentrations range from 0.9 to $2.7 \mathrm{wt} \%$, averaging $1.4 \mathrm{wt} \%$ in bog peat (B) and $1.8 \mathrm{wt} \%$ in fen peat (A) (Fig. 3). These values are similar to those reported for other permafrost peatlands (Vardy et al., 2000). In general, the patterns of $\mathrm{N}$ and TOC concentrations are similar except at $77.5 \mathrm{~cm}$ depth. Both parameters differ in the bog (B) versus fen (A) sections, exhibiting consistently lower values in the bog peat. The lowest $\mathrm{N}$ concentrations in the bog peat $(\mathrm{B})$ are in the Sphagnum layers (Bs) (Fig. 2). In section A2 of the fen peat, $N$ concentrations decrease with depth, coinciding with macrofossil evidence for an increasing abundance of mosses (Sphagnum other, Palludella squarosa). Low $\mathrm{N}$ concentrations also exist at the base of the core in section $\mathrm{A} 1$ of the fen peat, which is dominated by brown mosses. An exception to this trend exists at $220 \mathrm{~cm}$ depth where vascular plant macrofossils are more abundant (Fig. 2) and increases in concentrations of both TOC and N appear. In general, N concentrations appear to be linked strongly to plant assemblages and the prevailing nutrient status of the peatland at different times during its Holocene development, consistent with the suggestion by Vardy et al. (2000) that changes in plant species may control the $\mathrm{N}$ content of peat.

Organic matter hydrogen concentrations vary from 4.8 to $6.4 \%$, with a mean of $\sim 6 \mathrm{wt} \%$ in bog peat (B) and $5.8 \mathrm{wt} \%$ in fen peat (A). $\mathrm{H}$ concentration decreases in the $\mathrm{A} 2$ fen peat, which is dominated by vascular plant macrofossils (Fig. 2). The low $\mathrm{H}$ concentration of $4.2 \%$ at $100 \mathrm{~cm}$ may result from fewer aliphatic components (less mosses) or more lignin-rich compounds derived from vascular plants probably as a result of selective decomposition that produced more lignin-rich residues (Benner et al., 1987). $\mathrm{H}$ concentration increases deeper in the profile where macrofossils indicate that mosses coexisted with vascular plants. $\mathrm{H}$ concentration peaks at $>6 \%$ in fen peat at the bottom of the core in the $\mathrm{A} 1$ section where brown mosses dominated under very wet conditions (Fig. 2).

\section{Atomic $\mathrm{H} / \mathrm{C}$ ratios}

The LVPS4 + 5B peat profile consists of alternating successions of mosses and vascular plants with different relative dominances in time. On the basis of mosses being richer in aliphatic compounds and poorer in lignin compared to vascular plants, the $\mathrm{H} / \mathrm{C}$ proxy can potentially indicate the botanical and chemical compositions at different depths in the peat profile. However, post-depositional degradation introduces possible complications into the source identification potential of the $\mathrm{H} /$ $\mathrm{C}$ ratio. Despite being richer in aliphatic components than vascular plants, organic matter from mosses is not expected to decay faster, but slower, than organic matter from land plants. An explanation for this apparent contradiction exists in the observations of Karunen and Ekman (1982) who reported that shoots of Sphagnum fuscum become more resistant to decay during senescence because of the biosynthesis and accumulation of aliphatic lipid-derived polymers that resist degradation. Furthermore, many bryophytes contain large concentrations of phenolic compounds in their cell walls (e.g. Erickson and Miksche, 1974; Verhoeven and Liefveld, 1997), which together with non-polar compounds increase the recalcitrance of bryophyte organic matter by inhibiting microbial breakdown and making cell walls impenetrable to fungal hyphae (Verhoeven and Liefveld, 1997; Turetsky, 2003). Hence, bryophyte organic matter decomposes more slowly than vascular plant material. However, the question of whether lignin exists in bryophytes remains controversial. Lignin-like compounds have been detected in the cell walls of some species (Erickson and Miksche, 1974; Edelmann et al., 1998), but conclusive evidence remains lacking, even though Siegel (1969) reported the presence of true lignin in the giant mosses Dawsonia and Dendroligotrichum from New Zealand.

$\mathrm{H} / \mathrm{C}$ ratios in the LVPS4 $+5 \mathrm{~B}$ profile range from 1.27 to 1.66 (Fig. 3) and in the bog peat (B) values cluster around a ratio of 1.6, which is close to the $\mathrm{H} / \mathrm{C}$ ratio of 1.67 typical for cellulose (Kracht and Gleixner, 2000; Sevilla and Fuertes, 2009). H/C ratios of $\sim 1.6$ occur in peat layers where mosses are abundant, whereas the rootlet layer $(\mathrm{Br})$ at $20.5 \mathrm{~cm}$ in which Betula is dominant has the lowest $\mathrm{H} / \mathrm{C}$ ratio of 1.4 (Fig. 3). The range of $\mathrm{H} / \mathrm{C}$ values in fen peat (A) suggests that differences exist in the preservation of the organic matter with depth in this zone. The macrofossil content in the upper part of the fen peat (A2) is mainly dominated by vascular plants (Carex and Betula), and $\mathrm{H} / \mathrm{C}$ ratios decrease to a minimum of $1.27(100 \mathrm{~cm}$, no macrofossil information available), which is similar to the ratio 
reported for lignin compounds (Kracht and Gleixner, 2000). At this depth, this portion of the peat profile also has the lowest $\mathrm{H}$ concentration. The values of these geochemical proxies are consistent with the absence of recognizable plant macrofossil residues in this zone, indicating that organic material is highly degraded. The relative contribution of lignin from Carex and Betula cannot be determined from these data, but low $\mathrm{H} / \mathrm{C}$ ratios of this zone may be an indication of significant contributions of aromatic structures from decaying remains of herbaceous and woody material. In the lower part of the A2 fen deposit where vascular plants and mosses coexisted (Fig. 2), $\mathrm{H} / \mathrm{C}$ ratios increase to 1.6. The highest $\mathrm{H} / \mathrm{C}$ ratios (1.61-1.66) exist at the bottom of the peat profile in the A1 fen peat in which macrofossil content is dominated by brown mosses that probably accumulated under very wet conditions.

In general, the lowest $\mathrm{H} / \mathrm{C}$ ratios are present in the degraded upper part of the fen peat (A2) where Carex and Betula remains (Fig. 2) are most abundant, whereas the highest $\mathrm{H} / \mathrm{C}$ ratios seem to be associated with the presence of mosses in two areas: (i) in the bog peat (Bs) section that developed at the onset of permafrost, and (ii) under wetter anoxic conditions in A2 and A1 of the fen peat.

These observations suggest that the greater abundance of aliphatic structures in mosses is a consequence of either better preservation of organic matter under permafrost or wetter conditions, or is the aliphatic product of senescence in mosses as suggested by Karunen and Eckman (1982). Moreover, Bambalov (2011) reported that during humification aliphatic fragments of lignin in sedges become more abundant than in the original plant, suggesting that degradation of lignin in sedges also produces aliphatic structures. However, instead of increased evidence of aliphatic structures, we found low $\mathrm{H} / \mathrm{C}$ ratios similar to those of lignin at $80-100 \mathrm{~cm}$ in the peat sequence where macrofossils of vascular plants, including Carex, were most abundant and heavily degraded. This distribution could also be the result of selective degradation of aliphatic compounds in vascular plant debris that produces lignin-rich residues. Nonetheless, the observed trends in $\mathrm{H} / \mathrm{C}$ ratios probably also reflect the inherent resistance of mosses to decay.

\section{Atomic $C / N$ ratios}

The $\mathrm{C} / \mathrm{N}$ ratios in the Lek-Vorkuta peat sequence range from 20 to 60 (Fig. 3). Values are highest in the bog peat (B) dominated by Sphagnum section Acutifolia. The underlying fen peat (A) has lower $\mathrm{C} / \mathrm{N}$ ratios (mean $\sim 30$ ) that slowly increase towards the bottom of the profile.

The main source of $N$ in ombrotrophic peatlands is atmospheric deposition. In these bogs, Sphagnum mats respond quickly to $\mathrm{N}$ loading, retaining much of the deposited $\mathrm{N}$ (Vitt et al., 2003) before it reaches the anaerobic zone where denitrification occurs (Woodin and Lee, 1987). In contrast, vascular plants depend on nutrients released during organic matter decomposition. Thus, Sphagnum can restrict nutrient supply to vascular plants through interception of nutrients delivered by atmospheric deposition. Moreover, the recalcitrance of Sphagnum tissue minimizes decomposition, which further restricts the availability of $\mathrm{N}$ to vascular plants via SOM degradation (Limpens et al., 2006). Changes in the $\mathrm{C} / \mathrm{N}$ ratios in the bog peat (B) and in particular within the Sphagnum peat layers (Bs) may reflect preferential loss or translocation of $\mathrm{N}$, which increases $\mathrm{C} / \mathrm{N}$ values (Kuhry and Vitt, 1996; Wieder et al., 2010) (Fig. 3). However, the $\mathrm{C} / \mathrm{N}$ ratios in the fen peat $\mathrm{A} 2$ zone seem to be largely uniform, reflecting the continuous proportional decreases with depth in the concentrations of TOC and $\mathrm{N}$ within this zone. The lower $\mathrm{C} / \mathrm{N}$ ratios in zone $\mathrm{A} 2$ relative to the bog peat (B) may indicate that the fen peat is more degraded and has lost proportionally more $\mathrm{C}$ than $\mathrm{N}$ over time or they may be the consequence of the sections containing different plant assemblages.

$\mathrm{C} / \mathrm{N}$ ratios increase gradually with depth throughout the fen peat, with the highest values being in the lower fen peat (A1) where brown mosses were dominant under very wet conditions (Fig. 2). An exception exists at $220 \mathrm{~cm}$ in the unit where the $\mathrm{C} / \mathrm{N}$ ratio decreases and macrofossil data show that vascular plants were more abundant than mosses. $\mathrm{H} / \mathrm{C}$ ratios also increase with depth in the A2 and A1 fen zones, coincident with an increased abundance of mosses, probably because of greater proportions of aliphatic compounds associated with mosses. High $\mathrm{C} / \mathrm{N}$ and $\mathrm{H} / \mathrm{C}$ ratios in the bog peat $(\mathrm{B})$ and in the $\mathrm{A} 2$ and $\mathrm{A} 1$ fen peat probably reflect better preservation of organic matter owing to permafrost or to wetter and anoxic conditions in the fen peat before the onset of permafrost. However, the ratios also may be recording biogeochemical processes related to the cycling of $\mathrm{C}$ and $\mathrm{N}$ that differ for mosses and vascular plants in peatlands. For example, the $\mathrm{H} / \mathrm{C}$ ratio might reflect the aromatic versus aliphatic biochemical contributions of different plant assemblages. Higher values of this ratio seem to be associated with the presence of mosses and/or their senescence, an interesting process that makes their organic matter more resistant to decay. Higher values of this ratio were related to vascular plant debris in the range of lignin. As another example, high $\mathrm{C} / \mathrm{N}$ ratios may suggest preferential translocation of $\mathrm{N}$ relative to $\mathrm{C}$ into mosses, yielding higher values associated with better preserved material.

It is difficult to establish conclusively whether the observed changes in elemental proxies are caused predominantly by differences in biochemical composition of the plant assemblages, their particular decay processes or economies in use of $\mathrm{C}$ and $\mathrm{N}$. Moreover, it is uncertain to what extent paleoenvironmental conditions subsequently alter these proxies. Disentangling biochemical and environmental aspects is challenging because of their related impact on plant assemblages in peat profiles such as the one at Lek-Vorkuta. Results from a specific horizon in this profile serve as an illustration of the complexity of this issue. At $220 \mathrm{~cm}$ depth, vascular plants dominated, generating an abrupt decrease in the $\mathrm{C} / \mathrm{N}$ ratio, but the $\mathrm{H} / \mathrm{C}$ ratio remained high (Fig. 3). It cannot be determined conclusively whether these changes resulted from increased contributions of organic matter from mosses (mostly Drepanocladus) and/or their senescence, or as a consequence of wet conditions enhancing the preservation of organic matter.

\section{$\delta^{13} \mathrm{C}$ values of organic matter}

The $\delta^{13} \mathrm{C}$ values for organic matter in the LVPS4 $+5 B$ peat sequence range from -28.4 to $-25.3 \%$ (Fig. 3 ) and the average value is $-27.1 \%$. Fluctuations in $\delta^{13} \mathrm{C}$ values are greater in the bog $(B)$ than in fen $(A)$ peat, but all values are within the range generally associated with $C_{3}$ peat-forming plants (Ménot and Burns, 2001). The average $\delta{ }^{13} \mathrm{C}$ value of fen peat $(\mathrm{A})$ is $\sim 1 \%$ more negative than bog peat $(\mathrm{B})$, and there is a notable positive shift of $2.7 \%$ in $\delta^{13} \mathrm{C}$ values at the transition from fen to bog (44-48.5 cm depth). The $\delta^{13} \mathrm{C}$ values of bulk peat display an overall increasing trend with depth, similar to the SOM stable isotope values reported by Hornibrook et al. (2000) for a temperate zone peat bog in Canada, but opposite in direction to the values reported by Oksanen et al. (2001) for the Rogovaya River peat plateau in the Russian Arctic. The positive shift in $\delta{ }^{13} \mathrm{C}$ values with depth in the Lek-Vorkuta peatland appears to be related to changes in vegetation. The more negative $\delta{ }^{13} \mathrm{C}$ values in the bog peat (B) are associated with vascular plant remains (e.g. $-27.9 \%$ at $20.5 \mathrm{~cm}$ dominated by Betula), 
whereas the more positive values occur where Sphagnum mosses are dominant (Bs, Fig. 2). These differences in $\delta{ }^{13} \mathrm{C}$ values probably result from differences in the presence and abundance of key biochemical components that comprise peat-forming plants. For example, the cell walls of vascular plants are composed mainly of lignocellulose whereas those of mosses are composed primarily of cellulose (Benner et al., 1987; Kracht and Gleixner, 2000).

The positive shift in $\delta^{13} \mathrm{C}$ values from -28.0 to $-25.3 \%$ at $48.5-44 \mathrm{~cm}$ is associated with permafrost aggradation ca. $2500 \mathrm{cal}$ a BP as recorded in plant macrofossils (Fig. 2). Frost heave aerated the peat in the upper fen deposit (A2), leading to aerobic decay of that material. An abundance of Cenococcum fungal sclerotia at $48.5 \mathrm{~cm}$ also is indicative of drier conditions (Coleman et al., 1989). The shift in soil moisture and aeration driven by permafrost aggradation caused a change in vegetation from vascular plant (sedge)-dominated assemblages (upper part A2) to Sphagnum section Acutifolia and Betula (B) (Fig. 2).

The $\delta^{13} \mathrm{C}$ values in the deeper fen peat $(\mathrm{A})$ are generally more negative than the bog peat (B) but increase with depth to $-25.7 \%$ in basal layers where brown mosses become dominant (Fig. 2; with the exception of $220 \mathrm{~cm}$ depth where vascular plant remains are abundant). Strong correlations between TOC concentrations and $\delta^{13} \mathrm{C}$ values $(R=-0.9$, $n=12)$ and $\mathrm{C} / \mathrm{N}$ and $\delta^{13} \mathrm{C}$ values $(R=0.8, n=12)$ in the fen peat suggest that $\delta^{13} \mathrm{C}$ values are influenced by the amount and preservation of specific botanical constituents.

Nichols et al. (2009) suggested that $\delta^{13} \mathrm{C}$ values of Sphagnum in ombrotrophic peatlands are influenced by $\mathrm{CH}_{4}$ fluxes because methanotrophic bacteria live symbiotically within Sphagnum mosses (Raghoebarsing et al., 2005). Methanotrophy appears to provide additional $\mathrm{CO}_{2}$ to Sphagnum via oxidation of $\mathrm{CH}_{4}$ intercepted as it diffuses across the oxicanoxic interface in the acrotelm. Methane in wetlands, in particular ombrotrophic peatlands, has very negative $\delta^{13} \mathrm{C}$ values ( $\sim 85$ to $-55 \%$, Hornibrook, 2009), and its conversion to $\mathrm{CO}_{2}$ provides a potential source of ${ }^{13} \mathrm{C}$-depleted carbon for Sphagnum. Consequently, under wetter conditions higher rates of diffusive $\mathrm{CH}_{4}$ flux may cause a negative shift in the $\delta^{13} \mathrm{C}$ values of Sphagnum biomass. Although methanotrophic bacteria can consume considerable amounts of $\mathrm{CH}_{4}$ in wetlands (Hanson and Hanson, 1996; Segers, 1998), $\delta^{13} \mathrm{C}$ values of organic matter in the Lek-Vorkuta peatland appear to be minimally influenced by recycling of $\mathrm{CH}_{4}$, and the majority of change in peat $\delta{ }^{13} \mathrm{C}$ values with depth is best explained by shifts in vegetation type. The fen peat (A2) below the bog deposit (B) has the most negative $\delta^{13} \mathrm{C}$ values, and the macrofossil assemblage indicates a predominance of vascular plants. The $\mathrm{H} / \mathrm{C}$ and $\mathrm{C} / \mathrm{N}$ ratios in this zone suggest that the peat is highly degraded. However, $\delta^{13} \mathrm{C}$ values are similar to the lowest value measured in the bog peat (B) at $20.5 \mathrm{~cm}$ where Betula was dominant under permafrost conditions. These data support the suggestion by Skrzypek et al. (2010) that $\delta^{13} \mathrm{C}$ values of peat are not significantly impacted by diagenesis. The $\delta^{13} \mathrm{C}$ values are more positive in the lower part of the A2 fen deposit at the same depths where macrofossil data indicate that mosses coexisted with vascular plants (Fig. 2) and where $\mathrm{H} / \mathrm{C}$ and $\mathrm{C} / \mathrm{N}$ ratios increase. Similar to the bog peat (B), the presence of Sphagnum mosses is associated with more positive $\delta{ }^{13} \mathrm{C}$ values. The deepest fen peat (A1) contains the most ${ }^{13} \mathrm{C}$-enriched organic matter at depths where brown mosses were dominant (Calliergon). The $\delta{ }^{13} \mathrm{C}$ values in the $\mathrm{A} 1$ deposit are most similar to values measured in Sphagnum-rich bog peat (B), which formed after permafrost aggradation. The deep fen peat $(\mathrm{A})$ also has high $\mathrm{H} / \mathrm{C}$ and $\mathrm{C} / \mathrm{N}$ ratios, indicating the moss-rich material is well preserved. The negative $\delta^{13} \mathrm{C}$ value at $220 \mathrm{~cm}$ depth is associated with an increase in the abundance of vascular plant remains and is similar to values observed in the upper part of the A2 fen deposit where vascular plants were dominant.

Clymo and Bryant (2008) reported no changes in $\delta^{13} \mathrm{C}$ values of peat to a depth of $7 \mathrm{~m}$ in a raised bog, even at depths where $>60 \%$ of the original plant material had been lost due to decay. In bogs and fens, much of the plant biomass is metabolized higher in the chain of decay where no significant partitioning of $\mathrm{C}$ isotopes is associated with biological degradation. Discrimination of ${ }^{13} \mathrm{C}$ occurs primarily during the terminal stages of anaerobic $\mathrm{C}$ mineralization where $\mathrm{CH}_{4}$ (and $\mathrm{CO}_{2}$ ) are produced (Clymo and Bryant, 2008) and the amounts of energy and C cycled at that level are small relative to overall degradation of complex organic matter. The observed changes in $\delta^{13} \mathrm{C}$ values with depth are therefore most probably caused by differences in the relative accumulation of vascular plant and bryophyte remains and the differences that exist in their primary biochemical compositions.

\section{Changes in $\delta^{15} \mathrm{~N}$ values}

Approximately $95 \%$ of the $\mathrm{N}$ in peatland ecosystems is contained in dead organic matter (Rosswall and Granhall, 1980). Microbial mineralization of peat slowly makes a small fraction of organic $\mathrm{N}$ available to plants. In terrestrial ecosystems, loss of $\mathrm{N}$ under anaerobic conditions occurs mainly through microbial denitrification in which $\mathrm{NO}_{3}^{-}$is reduced to $\mathrm{N}_{2} \mathrm{O}$ and $\mathrm{N}_{2}$ or through anaerobic ammoniumoxidizing (anammox) bacteria that oxidize $\mathrm{NH}_{4}^{+}$to $\mathrm{N}_{2}$ using $\mathrm{NO}_{2}^{-}$. The latter process has been reported to occur in peat soil, including a permafrost peatland (Humbert et al., 2009; $\mathrm{Hu}$ et al., 2011). The roots of aerenchymatous plants (e.g. Carex, Eriophorum) contribute significantly to $\mathrm{N}$-cycling in wetlands by providing a niche for ammonia- and nitrite-oxidizing bacteria. Nitrate produced in this way can be used subsequently by denitrifying bacteria or taken up directly by plants (Bodelier et al., 1996).

In the Lek-Vorkuta peatland, $\delta^{15} \mathrm{~N}$ values of peat range from -0.6 to $5 \%$ with average values of $2.3 \%$ and $0.87 \%$ in bog (B) and fen (A) peat, respectively. A positive shift of $\sim 3 \%$ occurs in the bog deposit (B) immediately above the transition from fen (A2) peat. The excursion in $\delta^{15} \mathrm{~N}$ values to $5.5 \%$ between 48.5 and $44 \mathrm{~cm}$ depth (ca. $2500 \mathrm{cal}$ a BP) coincides with permafrost onset (Fig. 2). Frost heave of the peat surface lowered water table levels, allowing aerobic decay of organic matter. Regina et al. (1999) demonstrated that lowering of the water table in boreal peatlands increases $\mathrm{N}_{2} \mathrm{O}$ fluxes because nitrification is enhanced, which stimulates $\mathrm{N}$ mineralization of soil organic matter. Data from the Lek-Vorkuta peatland appear to be in agreement with that observation. An abundance of Cenococcum at $48.5 \mathrm{~cm}$ depth (Fig. 2) indicates a shift from wet to drier conditions, and during that transition enhanced nitrification would be followed by greater $\mathrm{N}$ mineralization, leaving the soil enriched in ${ }^{15} \mathrm{~N}$. The fen peat $(\mathrm{A})$ has low $\delta^{15} \mathrm{~N}$ values that further decrease gradually with depth. The $\delta^{15} \mathrm{~N}$ value of $\sim 0 \%$ at the base of the peat column where brown mosses are dominant (Fig. 2) is typical for ecosystems that receive low $\mathrm{N}$ input from atmospheric deposition (Kracht and Gleixner, 2000; Francioso et al., 2005).

Significant correlations do not exist between $\delta^{15} \mathrm{~N}$ values and $\delta^{13} \mathrm{C}$ values or TOC concentrations. However, $\delta^{15} \mathrm{~N}$ values in fen peat (A) correlate positively with $\mathrm{N}$ concentrations $(R=0.75, n=12)$ and negatively with $\mathrm{C} / \mathrm{N}$ ratios $(R=-0.74$, $n=12$ ), suggesting that under anoxic conditions more positive $\delta^{15} \mathrm{~N}$ values are associated with more degraded plant material. The most positive $\delta{ }^{15} \mathrm{~N}$ values at $100 \mathrm{~cm}$ depth in the fen peat 
are associated with low $\mathrm{H} / \mathrm{C}$ ratios and high $\mathrm{N}$ concentrations, consistent with nitrogen in vascular plants being made available primarily through microbial mineralization, which leaves a ${ }^{15} \mathrm{~N}$-enriched lignin residue (Francioso et al., 2005).

\section{Conclusions}

Elemental and stable isotope proxies analyzed in soil organic matter from the Lek-Vorkuta peatland provide insight into the complexity of $\mathrm{C}$ and $\mathrm{N}$ cycling in peatland ecosystems. The geochemical measurements conducted in concert with plant macrofossil analyses proved to be useful for characterizing $\mathrm{C}$ and $\mathrm{N}$ flow during long-term peatland development, demonstrating in particular key differences that occur in the cycling of these elements and more generally in organic matter in fens and bogs.

Atomic $\mathrm{H} / \mathrm{C}$ and $\mathrm{C} / \mathrm{N}$ ratios, supported by plant macrofossil data, are useful indicators of differences in the origin of organic matter, its decay and shifts in the dominant mechanisms of nitrogen allocation reflecting changes in vegetation. The $\mathrm{H} / \mathrm{C}$ ratio appears to be a sensitive indicator of the aromatic versus aliphatic biochemical composition of plant organic matter. Higher values in the Lek-Vorkuta peat sequence are associated with mosses and/or their senescence, suggesting that peat derived from moss is more resistant to degradation than organic matter from vascular plants. The elemental data also indicate that mosses have a higher capacity than vascular plants to intercept nitrogen.

Changes of $\delta^{15} \mathrm{~N}$ values with depth appear to be controlled primarily by $\mathrm{N}$ isotope fractionation associated with microbial decomposition of plant detritus and peat. In contrast, changes in $\delta^{13} \mathrm{C}$ values of peat are determined mainly by succession and shifts in composition of dominant plant communities. Diagenesis of peat appears to have had minimal impact on $\delta^{13} \mathrm{C}$ values of organic matter in the Lek-Vorkuta peatland. The effect of the permafrost aggradation that drove the transition from fen peatland to plateau bog at $\sim 2500$ cal a BP was clearly evident in all elemental and isotopic measurements, confirming the utility of these geochemical proxies for reconstructing the accumulation history and decomposition trajectories of organic matter in global peatland ecosystems.

Given the complex plant assemblage in the peat profile, changes in degradation observed in the elemental and isotopic proxies seem to be related primarily to contributions from specific types of plants. However, important questions remain that need further investigation. Studies on the variability of peat degradation based on a single functional plant will help in this regard.

Acknowledgements. We are grateful for the suggestions and comments from two anonymous reviewers that helped to improve this paper. We thank Heike Siegmund and the Stable Isotope Laboratory (SIL, Stockholm University) for assistance with conducting the elemental and isotopic analyses. We are grateful for helpful comments from Prof. Riks Laanbroek. Collection of the LVPS4 and 5B cores was funded through the EU-funded TUNDRA (Contract no. ENV4-CT97-0522) and PERUSA (Contract no. INTAS-OPEN-97-10984) projects (to P.Kuhry).

Abbreviations. SOM, soil organic matter; TOC, total organic carbon.

\section{References}

Alewell C, Giesler R, Klaminder J, et al. 2011. Stable carbon isotopes as indicators for micro-geomorphic changes in palsa peats. Biogeosciences Discussions 8: 527-548.

Andersson RA, Kuhry P, Meyers P, et al. 2011. Impacts of paleohydrological changes on n-alkane biomarker compositions of a Holocene peat sequence in the Eastern European Russian Arctic. Organic Geochemistry 42: 1065-1075.
Balesdent J, Mariotti A, Guillet B. 1987. Natural ${ }^{13} \mathrm{C}$ abundance as a tracer for studies of soil organic matter dynamics. Soil Biology and Biochemistry 19: 25-30.

Balesdent J, Mariotti A. 1998. Measurement of SOM turnover using ${ }^{13} \mathrm{C}$ natural abundance. In Mass Spectrometry of Soils, Boutton TW, Yamasaki S. (eds). Marcel Dekker: New York; 83-111.

Bambalov N. 2011. Changes in the elemental composition of lignin during humification. Eurasian Soil Science 44: 1090-1096.

Barber KE. 1993. Peatlands as scientific archives of past biodiversity. Biodiversity and Conservation 2: 474-489.

Benner R, Fogel M, Sprague EK, et al. 1987. Depletion of 13C in lignin and its implication for stable isotope studies. Nature 329: 708-710.

Bodelier PLE, Libochant JA, Blom C, et al. 1996. Dynamics of nitrification and denitrification in root-oxygenated sediments and adaptation of ammonia-oxidizing bacteria to low-oxygen or anoxic habitats. Applied Environmental Microbiology 62: 4100-4107.

Bol RA, Harkness DD, Huang Y, et al. 1999. The influence of soil processes on carbon isotope distribution and turnover in the British uplands. European Journal of Soil Science 50: 41-51.

Caseldine CJ, Baker A, Charman DJ, et al. 2000. A comparative study of optical properties of $\mathrm{NaOH}$ peat extracts: implications for humification studies. The Holocene 10: 649-658.

Chambers FM, Booth RK, De Vleeschouwer F, et al. 2012. Development and refinement of proxy-climate indicators from peats. Quaternary International. In press. [doi: 10.1016/j.quaint.2011.04.039].

Clymo RS, Bryant CL. 2008. Diffusion and mass flow of dissolved carbon dioxide, methane, and dissolved organic carbon in a 7-m deep raised peat bog. Geochimica et Cosmochimica Acta 72: 20482066.

Coleman M, Bledsoe C, Lopushinsky W. 1989. Pure culture response of ectomycorrhizal fungi to imposed water stress. Canadian Journal of Botany 67: 29-39.

Davidson EA, Janssens IA. 2006. Temperature sensitivity of soil carbon decomposition and feedbacks to climate change. Nature 440: 165173.

Edelmann HG, Neinhuis C, Jarvis M, et al. 1998. Ultrastructure and chemistry of the cell wall of the moss Rhacocarpus purpurascens (Rhacocarpaceae): a puzzling architecture among plants. Planta 206: 315-321.

Erickson M, Miksche GE. 1974. On the occurrence of lignin or polyphenols in some mosses and liverworts. Phytochemistry 13: 22952299.

Farquhar GD, Ehleringer JR, Hubick KT. 1989. Carbon isotope discrimination and photosynthesis. Annual Review of Plant Physiology and Plant Molecular Biology 40: 503-537.

Francioso O, Montecchio D, Gioacchini P, et al. 2005. Thermal analysis (TG-DTA) and isotopic characterization $(13 \mathrm{C}-15 \mathrm{~N})$ of humic acids from different origins. Applied Geochemistry 20: 537-544.

Hanson R, Hanson T. 1996. Methanotrophic bacteria. Microbiological Reviews 60: 439-471.

Hayes JM. 1993. Factors controlling 13C contents of sedimentary organic compounds: principles and evidence. Marine Geology 113: $111-125$.

Hornibrook ERC, Longstaffe FJ, Fyfe WS, et al. 2000. Carbon isotope ratios and carbon, nitrogen and sulfur abundances in flora and soil organic matter from a temperate-zone bog and marsh. Geochemical Journal 34: 237-245.

Hornibrook ERC. 2009. The stable carbon isotope composition of methane produced and emitted from northern peatlands. In Northern Peatlands and Carbon Cycling, Baird A, Belyea L, Comas X, et al. (eds). American Geophysical Union: Washington, DC; 187-203.

Hu B-I, Rush D, van der Biezen E, et al. 2011. New anaerobic, ammonium-oxidizing community enriched from peat soil. Applied Environmental Microbiology 77: 966-971.

Humbert S, Tarnawski S, Fromin N, et al. 2009. Molecular detection of anammox bacteria in terrestrial ecosystems: distribution and diversity. ISME J 4: 450-454.

Jones MC, Peteet DM, Sambrotto R. 2010. Late-glacial and Holocene $\boldsymbol{\delta} 15 \mathrm{~N}$ and $\boldsymbol{\delta} 13 \mathrm{C}$ variation from a Kenai Peninsula, Alaska peatland. Palaeogeography, Palaeoclimatology, Palaeoecology 293: 132-143.

Kaislahti Tillman P, Holzkämper S, Kuhry P, et al. 2010. Stable carbon and oxygen isotopes in Sphagnum fuscum peat from subarctic 
Canada: implications for palaeoclimate studies. Chemical Geology 270: 216-226.

Karunen P, Ekman R. 1982. Age-dependent content of polymerized lipids in Sphagnum fuscum. Physiologia Plantarum 54: 162-166.

Kracht O, Gleixner G. 2000. Isotope analysis of pyrolysis products from Sphagnum peat and dissolved organic matter from bog water. Organic Geochemistry 31: 645-654.

Kuhry P, Vitt DH. 1996. Fossil carbon/nitrogen ratios as a measure of peat decomposition. Ecology 77: 271-275.

Lemke P, Ren J, Alley RB, et al. 2007. Observations: changes in snow, ice and frozen ground. In Climate Change 2007: The Physical Science Basis. Contribution of Working Group I to the Fourth Assessment Report of the Intergovernmental Panel on Climate Change, Solomon S, Qin D, Manning M, et al. (eds). Cambridge University Press: Cambridge; 337-383.

Limpens J, Hejmans M, Berendse F. 2006. The nitrogen cycle in boreal peatlands. In Boreal Peatland Ecosystems, Wieder RK, Vitt DH. (eds). Springer-Verlag Berlin and Heidelberg GmbH \& Co. K: Berlin; 195-230.

Loader NJ, McCarroll D, van der Knaap WO, et al. 2007. Characterizing carbon isotopic variability in Sphagnum. The Holocene 17: 403410.

Ménot G, Burns SJ. 2001. Carbon isotopes in ombrogenic peat bog plants as climatic indicators: calibration from an altitudinal transect in Switzerland. Organic Geochemistry 32: 233-245.

Meyers PA. 1994. Preservation of elemental and isotopic source identification of sedimentary organic matter. Chemical Geology 114: 289302.

Moschen R, Kühl N, Rehberger I, et al. 2009. Stable carbon and oxygen isotopes in sub-fossil Sphagnum: Assessment of their applicability for palaeoclimatology. Chemical Geology 259: 262-272.

Nadelhoffer K, Shaver G, Fry B, et al. 1996. 15N natural abundances and $\mathrm{N}$ use by tundra plants. Oecologia 107: 386-394.

Nichols JE, Walcott M, Bradley R, et al. 2009. Quantitative assessment of precipitation seasonality and summer surface wetness using ombrotrophic sediments from an Arctic Norwegian peatland. Quaternary Research 72: 443-451.

Oksanen PO, Kuhry P, Alekseeva RN. 2001. Holocene development of the Rogovaya River peat plateau, European Russian Arctic. The Holocene 11: 25-40.

Ortiz JE, Torres T, Delgado A, et al. 2004. The palaeoenvironmental and palaeohydrological evolution of Padul Peat Bog (Granada, Spain) over one million years, from elemental, isotopic and molecular organic geochemical proxies. Organic Geochemistry 35: 12431260.

Raghoebarsing AA, Smolders AJP, Schmid MC, et al. 2005. Methanotrophic symbionts provide carbon for photosynthesis in peat bogs. Nature 436: 1153-1156.

Regina K, Silvola J, Martikainen PJ. 1999. Short-term effects of changing water table on $\mathrm{N}_{2} \mathrm{O}$ fluxes from peat monoliths from natural and drained boreal peatlands. Global Change Biology 5: 183-189.
Rosswall T, Granhall U. 1980. Nitrogen cycling in a subarctic ombrotrophic mire. Ecological Bulletins 209-234.

Sannel ABK, Kuhry P. 2009. Holocene peat growth and decay dynamics in sub-arctic peat plateaus, west-central Canada. Boreas 38: $13-24$.

Segers R. 1998. Methane production and methane consumption: a review of processes underlying wetland methane fluxes. Biogeochemistry 41: 23-51.

Sevilla M, Fuertes AB. 2009. The production of carbon materials by hydrothermal carbonization of cellulose. Carbon 47: 2281-2289.

Siegel SM. 1969. Evidence for the Presence of Lignin in Moss Gametophytes. American Journal of Botany 56: 175-179.

Skrzypek G, Kaluzny A, Wojtun B, et al. 2007. The carbon stable isotopic composition of mosses: A record of temperature variation. Organic Geochemistry 38: 1770-1781.

Skrzypek G, Jezierski P, Szynkiewicz A. 2010. Preservation of primary stable isotope signatures of peat-forming plants during early decomposition - observation along an altitudinal transect. Chemical Geology 273: 238-249.

Talbot MR, Livingstone DA. 1989. Hydrogen index and carbon isotopes of lacustrine organic matter as lake level indicators. Palaeogeography, Palaeoclimatology, Palaeoecology 70: 121-137.

Tarnocai C, Canadell J, Schuur E, et al. 2009. Soil organic carbon pools in the northern circumpolar permafrost region. Global Biogeochemical Cycles 23: GB2023. DOI: 2010.1029/2008GB003327.

Turetsky MR. 2003. New frontiers in bryology and lichenology: the role of bryophytes in carbon and nitrogen cycling. Bryologist 106: 395409

Vardy SR, Warner BG, Turunen J, et al. 2000. Carbon accumulation in permafrost peatlands in the Northwest Territories and Nunavut, Canada. The Holocene 10: 273-280.

Verhoeven JTA, Liefveld WM. 1997. The ecological significance of organochemical compounds in Sphagnum. Acta Botanica Neerlandica 46: 117-130.

Virtanen T, Mikkola K, Nikula A. 2004. Satellite image based vegetation classification of a large area using limited ground reference data: a case study in the Usa Basin, north-east European Russia. Polar Research 23: 51-66.

Vitt D, Wieder R, Halsey L, et al. 2003. Response of Sphagnum fuscum to nitrogen deposition: a case study of ombrogenous peatlands in Alberta, Canada. The Bryologist 106: 235-245.

Werth M, Kuzyakov Y. 2010. 13C fractionation at the root-microorganisms-soil interface: a review and outlook for partitioning studies. Soil Biology and Biochemistry 42: 1372-1384.

Wieder R, Vitt D, Burke-Scoll M, et al. 2010. Nitrogen and sulphur deposition and the growth of Sphagnum fuscum in bogs of the Athabasca Oils Sands Region, Alberta. Journal of Limnology 69: 161-170.

Woodin SJ, Lee JA. 1987. The fate of some components of acidic deposition in ombrotrophic mires. Environmental Pollution 45: $61-72$. 